This is an Accepted Manuscript of an article published by Emerald Insight in IJSHE, available at: http://www.emeraldinsight.com/doi/abs/10.1108/IJSHE-12-2013-0166?af=R

\title{
Developing Students' Energy Literacy in Higher Education
}

Author 1 Name: Professor Debby R E Cotton

Department: Pedagogic Research Institute and Observatory (PedRIO)

University/Institution: Plymouth University

Town/City: Plymouth

Country: UK

Author 2 Name: Dr Wendy Miller

Department: Pedagogic Research Institute and Observatory (PedRIO)

University/Institution: Plymouth University

Town/City: Plymouth

Country: UK

Author 3 Name: Dr Jennie Winter

Department: Pedagogic Research Institute and Observatory (PedRIO)

University/Institution: Plymouth University

Town/City: Plymouth

Country: UK

Author 4 Name: Dr lan Bailey

Department: School of Geography, Earth and Environmental Sciences

University/Institution: Plymouth University

Town/City: Plymouth

Country: UK

Author 5 Name: Professor Stephen Sterling

Department: Centre for Sustainable Futures

University/Institution: Plymouth University

Town/City: Plymouth

Country: UK 
This is an Accepted Manuscript of an article published by Emerald Insight in IJSHE, available at: http://www.emeraldinsight.com/doi/abs/10.1108/IJSHE-12-2013-0166?af=R

\section{Article history:}

Received 20-Dec-2013

Received in revised form 13-May-2014

Accepted 30-June-2014

\section{Structured abstract}

Purpose: Developing students' energy literacy is a key part of the 'greening' agenda, yet little is known about how students develop their ideas about energy use and energy saving at university. This paper investigates students' energy literacy at a UK university, and recommends ways in which it can be enhanced using a behaviour change model.

Design/methodology/approach: The research utilised a mixed-methods approach including an online survey (with 1136 responses) and focus groups.

Findings: The research identified strengths and weaknesses in students' energy literacy, and noted the relative influence of formal and informal curricula. The potential for aligning these curricula is highlighted through the 4 Es model of enable, engage, exemplify and encourage.

Research limitations/implications* The research involved a single instrumental case-study site. The wider applicability of the findings should therefore be tested further in other institutions.

Practice implications* The research suggests ways in which universities might better support their students in making more sustainable energy-related behaviour choices, and indicates the importance of knowledge as well as attitudes.

Social implications* The research may have implications for the energy-saving behaviours of individuals in wider society.

Originality/value: Attempts to reduce energy use in higher education are widely seen in campus operations. This research provides an indication of the potential for enhancing energy-saving through different forms of curricula.

[* if applicable]

Keywords: University students; energy literacy; energy behaviours; formal and informal curricula

Article classification: Research paper 
This is an Accepted Manuscript of an article published by Emerald Insight in IJSHE, available at: http://www.emeraldinsight.com/doi/abs/10.1108/lJSHE-12-2013-0166?af=R

\section{Developing Students' Energy Literacy in Higher Education}

\section{Introduction}

Higher Education (HE) has a key role to play in educating 'leaders for the future' (Martin and Jucker, 2005), and there is an increasing expectation that higher level study should play a leading role in equipping graduates with the knowledge, skills and attitudes which enable them to respond appropriately to sustainability challenges (see for example The Higher Education Funding Council for England (HEFCE), 2013). However, conjecture surrounds the extent to which HE is rising to this challenge. Orr (1994), for example, claims that there is no clear correlation between educational level and environmental concern:

'The conventional wisdom holds that all education is good, and the more of it one has, the better... The truth is that without significant precautions, education can equip people merely to be more effective vandals of the earth' (p.5).

In contrast, Cotton and Alcock (2012) cite evidence from the UK that a positive correlation does exist between participation in $\mathrm{HE}$ and subsequent commitment to environmental sustainability when other factors are held constant. Although this does not prove direct causation, this research hints that universities might play a role in preparing graduates for dealing with sustainability issues such as climate change.

Despite the growing discussion of sustainability literacy and competences (Stibbe, 2009; Wiek et al., 2011) and the importance of climate change as an issue of international concern, the development of students' 'energy literacy' has received relatively little attention in the research literature. Where energy issues do appear, the focus is mainly on campus greening or energy-reduction schemes, particularly in student residences. Additionally, the emphasis of such schemes is predominantly on behaviour change rather than the wider concept of energy literacy, an emphasis that may considerably restrict their longer-term impacts. According to DeWaters and Powers (2011), energy literate graduates would have the skills to "make informed energy-related choices as they go about their daily life" (p.10) based on:

- knowledge and understanding about energy, its use and impact on environment and society (cognitive); 
This is an Accepted Manuscript of an article published by Emerald Insight in IJSHE, available at: http://www.emeraldinsight.com/doi/abs/10.1108/IJSHE-12-2013-0166?af=R

- appropriate attitudes and values, for example, on existence of global issues and the significance of personal decisions and actions (affective); and

- appropriate intentions/behaviours, for example to promote energy conservation, make thoughtful decisions, advocate change (conative).

This conceptualization of energy literacy is manifestly more challenging for individuals than simply following instructions to reduce energy in student accommodation, not least because it implies far-reaching transformations spanning understandings, attitudes and behaviours. It also poses significant challenges in terms of ensuring consistency across all higher education activities, including research, teaching and estate management in support of energy literacy (Tilbury, 2011). A 2008 review by the Higher Education Funding Council for England (HEFCE), which included energy use in $\mathrm{HE}$, similarly indicated that full commitment to 'greening' campus operations was only identifiable where the 'talk' in research and teaching is 'walked' in estates practice (p.61). While many students are exposed to opportunities to learn about sustainability issues through the formal university curriculum, significant variations in provision exist depending upon the programme or course studied (see Dahle and Neumayer, 2001; Hopkinson et al., 2008; Cotton et al., 2009; Stewart, 2010; Emanuel and Adams, 2011). Nonetheless, there are signs that some universities are seeking to integrate sustainability into the curriculum, as well as through campus management, community relations and other avenues that open up new opportunities for informal learning across the disciplines (Sterling et al., 2013).

The need for a more integrated approach to energy literacy is further illustrated by evidence from previous research that both students and the public have a patchy understanding of energy issues (Barrow \& Morrissey, 1989; DeWaters and Powers, 2011; Attari et al., 2010), and that, although high levels of concern about energy are frequently expressed, lower levels of knowledge and skills tend to prevail. However, little research has focused explicitly on the ways in which energy literacy might be developed in HE. To become energy literate students must be challenged to think and have dialogue about energy, raising it out of a practical domain and into a discursive consciousness (Giddens, 1991). The university campus can offer a discipline-neutral site where energy issues can be made manifest for students to consider and respond to (Jucker, 2002). However, in one of the few existing papers focusing on energy in $\mathrm{HE}$, Van Treuren and Gravagne (2008) suggest that the state of energy education in higher education is dismal' and that curriculum coverage of energy issues is generally narrow: most disciplines only deal with a single aspect of 
This is an Accepted Manuscript of an article published by Emerald Insight in IJSHE, available at: http://www.emeraldinsight.com/doi/abs/10.1108/lJSHE-12-2013-0166?af=R

energy - either technical material (e.g. how electricity is generated) or social content (e.g. policy regarding energy usage). In addition, research in the UK (Kagawa, 2007; Winter and Cotton, 2012) suggests that students are highly aware of energy issues yet want more information about energy use and are often confused about energyefficient behavioural choices.

More widely, previous sustainability research suggests that significant scope exists for improving the integration between campus and curriculum, and for aligning the formal and informal curricula. Hopkinson et al. (2008) note that, despite the increasing enthusiasm for sustainability in HE:

'the student experience at most universities typically has a fragmented connection to the values, ideals and practical aspects of living, studying or working in a sustainable way' (p.439).

Djordjevic and Cotton (2011) and Winter and Cotton (2012), meanwhile, indicate that communication about sustainability through official channels, or sustainability education in the formal curriculum, can be subverted by competing or conflicting messages in the campus environment. For example, whilst curricula may discuss the potential of renewables such as wind or solar power, there are no installations visible on campus. Given that a significant proportion of student learning happens outside structured teaching and learning contexts (Barth, 2013), these are important constraints on the development of energy literacy in $\mathrm{HE}$.

The aim of this paper is to help to bridge gaps in current understandings of how $\mathrm{HE}$ might contribute more actively to the enhancement of energy literacy. The paper is based on a study of students' energy literacy in an institution which has been generally recognised (for example, in the UK People and Planet Green League ${ }^{7}$ ) as successful in integrating sustainability within $\mathrm{HE}$. It aimed to investigate the ways and extent to which students' energy use, attitudes and behaviours are influenced by formal and informal curricula. As a device for exploring the various ways in which $\mathrm{HE}$ might contribute to enhancing energy literacy, we employed the UK Department for Environment, Food and Rural Affairs' (DEFRA's) 4E behaviour change model (see Figure 1).

$\left[{ }^{1}\right.$ http://peopleandplanet.org/greenleaque 
This is an Accepted Manuscript of an article published by Emerald Insight in IJSHE, available at: http://www.emeraldinsight.com/doi/abs/10.1108/IJSHE-12-2013-0166?af=R 
This is an Accepted Manuscript of an article published by Emerald Insight in IJSHE, available at: http://www.emeraldinsight.com/doi/abs/10.1108/IJSHE-12-2013-0166?af=R

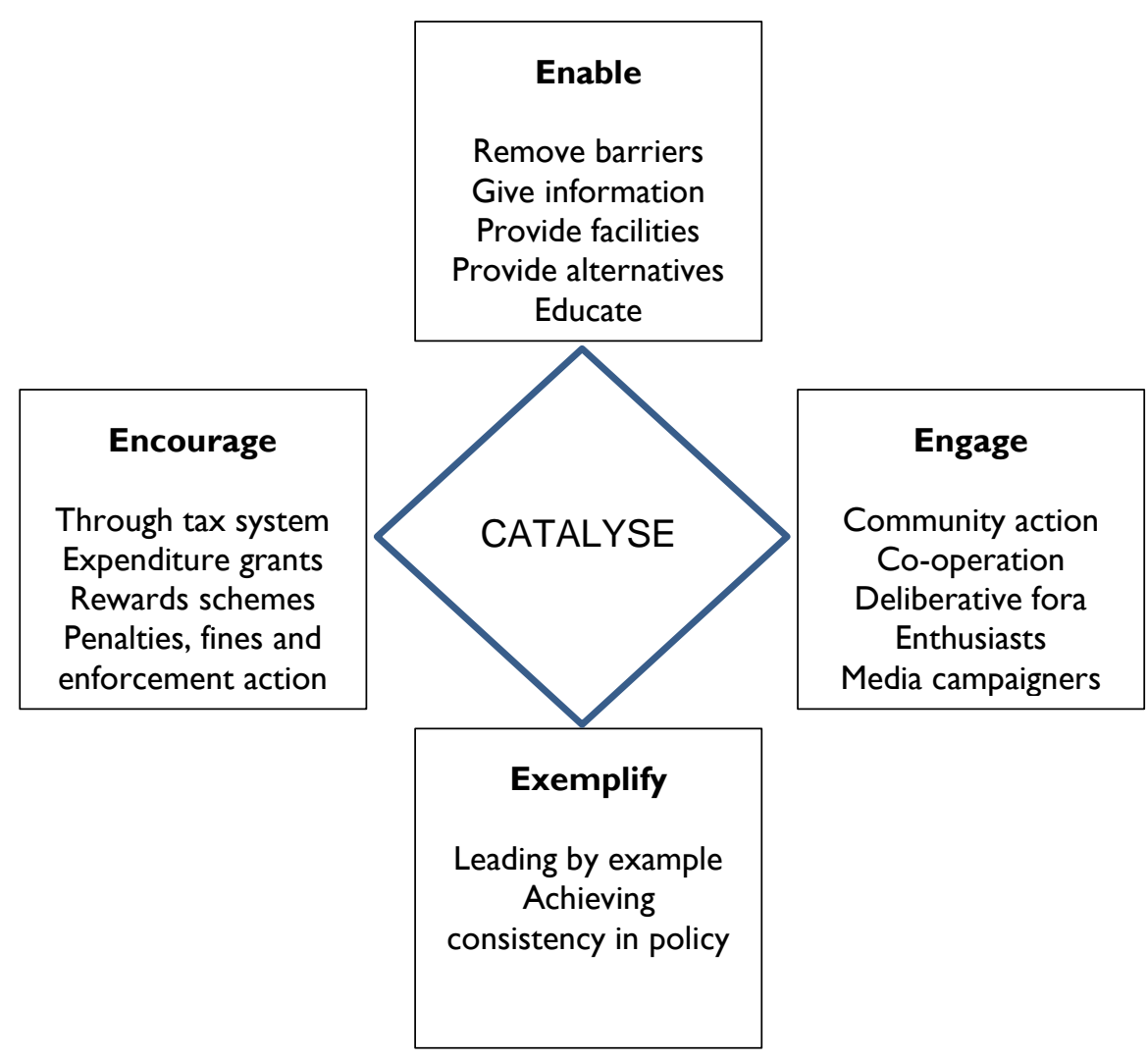

Figure 1. Adapted by authors from DEFRA's $4 E$ behaviour change model (DEFRA, 2005)

The 4E model is of particular value for the task of exploring energy literacy because it explicitly recognises and targets segments of the population with different attitudes and responses to sustainability issues. These range from the uninterested and partially-engaged to more concerned individuals who may be inhibited from practising more sustainable energy behaviours by lack of knowledge, structural factors or financial limitations. Students within HE institutions are likely to comprise all such groups, thus, a range of measures including more active methods (Enable and Encourage) and softer approaches (Exemplify and Engage) are likely to be needed to respond to different contexts and constraints. According to DEFRA (2005), "Enable" stresses enhancing the availability and accessibility of sustainable alternatives (and may include information provision through the formal curriculum); "Encourage" aims at reforms that, for example, improve the affordability of sustainable products and practices; "Exemplify" invites consistent action by institutions as a means of encouraging through leading by example; whilst "Engage" refers to actions that help create enthusiasm and commitment among different 
This is an Accepted Manuscript of an article published by Emerald Insight in IJSHE, available at: http://www.emeraldinsight.com/doi/abs/10.1108/lJSHE-12-2013-0166?af=R

target audiences (DEFRA, 2008). The model thus facilitates exploration of the wide range of institutional activities which might impact on students' energy literacy.

\section{Methodology}

The research took the form of an instrumental case study (Stake, 1995) to explore the issue of energy literacy through studying students at a UK university. An instrumental case study uses a single institution to explore and exemplify a wider issue (in this case students' energy literacy). The case-study approach was chosen on the basis of its strong grounding in reality and the ability to generate a rich, detailed account. Generalization in this study thus takes the form of 'theoretical inference' (Hammersley 1998), in which the conclusions move beyond the claims made about the individual case to a more general, theoretical level that is potentially of wider interest. Any theoretical understanding produced must therefore be considered provisional in nature and would benefit from further investigation.

The university selected, Plymouth University, is the sixth largest in England, has achieved ISO $14001^{2}$ for monitoring and improving environmental performance, and has been nationally recognised for its achievements in sustainability (it is the overall front-runner since 2007 in the UK People and Planet Green League). It received funding from the Higher Education Funding Council for England (HEFCE) in 2005 under the CETL (Centres for Excellence in Teaching and Learning) scheme ${ }^{3}$ to set up the Centre for Sustainable Futures, and has won several 'Green Gown Awards'4. It has also been a recipient of Revolving Green Fund ${ }^{5}$ monies from HEFCE to embed energy saving measures, and was of the first two HEls to gain Silver Accreditation in the LIFE (Learning in Future Environments) programme ${ }^{6}$. Thus, it provides a context in which curriculum and campus greening issues have been taken seriously.

Plymouth University's Sustainability Strategy 2009-2014 commits to "engaging all students with sustainability concepts and issues in an appropriate learning context" (p.4). Its Energy and Water Policy 2012-2015 "endorses the principle that energy and water conservation is of paramount importance", and contains a carbon reduction target of $25 \%$ by 2015 from a 2005 baseline. (In 2011 it also committed to achieving

\footnotetext{
2 http://peopleandplanet.org/greenleague

3 http://www.hefce.ac.uk/whatwedo/lt/enh/cetl/

4 http://www.eauc.org.uk/green gown awards

5 http://www.hefce.ac.uk/whatwedo/lgm/sd/rgf/

6 http://www.thelifeindex.org.uk/
} 
This is an Accepted Manuscript of an article published by Emerald Insight in IJSHE, available at: http://www.emeraldinsight.com/doi/abs/10.1108/IJSHE-12-2013-0166?af=R

carbon neutrality by 2030.) In 2012 the Students' Union achieved an NUS Green Impact ${ }^{7}$ Gold accreditation, and all students are invited to a talk on sustainability during their induction. However, there is no on-going cross-disciplinary or crosssector network that regularly involves students in collaboration over issues of energy use on campus, a factor suggested by Kurland (2011) as enabling broader support for sustainability (p.413). Further, whilst students in some disciplines such as engineering, have opportunities to learn about campus carbon management, the majority do not engage with campus operations or facilities staff during their time at the institution. The institution therefore provides a context in which sustainability is taken seriously, but in which energy education and energy literacy have not, thus far, been a particularly high profile part of university activities.

The research entailed a mixed methods approach comprising an online survey followed up by focus-group interviews with selected students. The survey contained 40 questions exploring energy knowledge, attitudes and behaviours, and consisted of a mix of ranking, Likert-type scale, closed and open questions. Some questions were developed by the research team, and others were incorporated from previous (mainly UK and US) surveys on energy and environmental values and behaviours (Holden and Barrow 1984; Holmes 1987; Dunlap et al. 2000; Curry et al. 2005; Poortinga 2005; DeWaters 2009; Brewer et al. 2011; Dwyer 2011; Bodzin et al. 2012; Du Plessis et al., 2012). The section on energy knowledge included questions probing general understandings of energy systems, for example, which sources provide over $85 \%$ of energy in the UK (fossil fuels), and more technical questions, such as which type of light bulb uses least energy (LED). The survey also incorporated the widelyused New Ecological Paradigm (NEP) scale (Dunlap, 2008), as well as our own questions on perceptions of social and environmental priorities (strengthening the economy, reducing inequality, etc.). The NEP was used because it provides a validated scale of individuals' attitudes and concerns about environmental issues, and indicates the extent to which respondents ascribe to an ecocentric (values centred on ecology) or technocentric (values centred on technology) worldview (see O'Riordan, 1981 for further discussion of these positions). Despite concerns about some the language used in the NEP scale (see Lundmark, 2007), its inclusion also facilitates comparison with wider surveys of environmental attitudes. The section on behaviours asked respondents about their own behavioural practices, such as paying more for environmentally products, or turning heat down in rooms.

${ }^{7}$ http://www.green-impact.org.uk/ 
This is an Accepted Manuscript of an article published by Emerald Insight in IJSHE, available at: http://www.emeraldinsight.com/doi/abs/10.1108/IJSHE-12-2013-0166?af=R

The student survey was carried out via Survey Monkey, in the spring term of 2013, and was publicised via School administrators and on screens and noticeboards around campus. 1136 responses were received from all Faculties and Schools (equating to a $6.3 \%$ response rate from the target student population). Whilst less than ideal, this response rate is not dissimilar to that obtained in similar online surveys (e.g. Kagawa, 2007) and meets critical thresholds for generalisation. The survey was followed up by four student focus groups in the summer term of 2013, where students were selected to provide as wide a range of discipline backgrounds as possible. The focus groups enabled us to probe the reasoning behind views and behaviours issues further in order to gain richer data on students' experiences of learning about energy in higher education. Responses were analysed using SPSS to explore frequencies and relationships between different variables and relationships between variables were tested using Chi-square tests where appropriate. Coding of qualitative data (from open questions and focus groups) utilised the constant comparative method to draw out cross-cutting themes (Silverman, 2005), and an iterative process of re-reading data to identify similarities and differences between accounts. The results presented in this paper focus on the quantitative and qualitative questionnaire data exploring students' current energy literacy and the relative contributions of formal and informal curricula to energy literacy.

\section{Findings}

\subsection{Respondents' energy literacy}

This section summarises the respondents' energy literacy in terms of the cognitive, affective and conative elements discussed earlier. Subsequent sections explore the possible origins of different elements of students' energy literacy and the potential for further change. Reported knowledge about energy issues was generally high, with a majority of survey respondents (81.2\%) stating that they knew either 'quite a bit' or 'a medium amount' about energy (Figure 2). Male students were more likely than female students to pick the top two points on the scale, and they were also significantly more likely than females to respond correctly to some factual questions (for example about which type of light bulb used the least energy, $p<0.01$ ). This finding suggests that there was some validity to the self-reported knowledge claims made by respondents - although gender differences in self-confidence may also have influenced responses. 


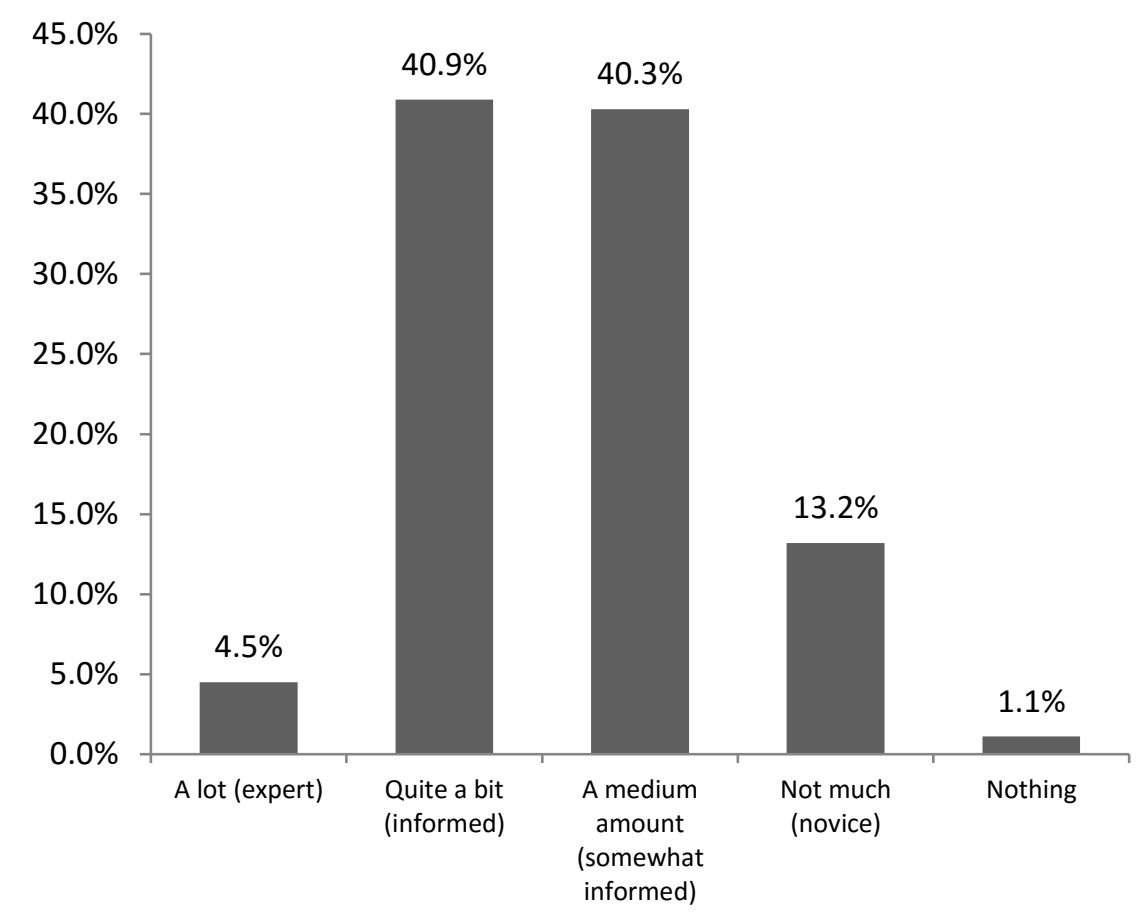

Figure 2. 'How much do you feel you know about energy?' $(\mathrm{n}=1136)$

In relation to environmental worldviews, the respondent group tended towards the ecological end of the New Ecological Paradigm (NEP) scale, the overall mean score for which was 2.34 where 1 =ecocentric and $5=$ technocentric. This represents a higher proportion of ecological worldviews than has been found in comparable surveys in other HE contexts (e.g. Shephard et al., 2009, Hawcroft and Milfont, 2010). When asked about the importance of energy compared with other issues, the strongest area of concern was 'strengthening the economy' (rated as the 'most important current issue' by $25.4 \%$ of respondents). However, 'limiting climate change' was the second most commonly cited (at $18.8 \%$ of respondents), and ensuring a 'secure energy supply' polled $12.6 \%$. This suggests that respondents had broadly positive attitudes towards sustainability generally, and were concerned about energy issues in particular.

When asked to rate their personal energy use, $60 \%$ of respondents stated that they were medium energy users, with $18 \%$ low energy users and $17 \%$ moderately high 
This is an Accepted Manuscript of an article published by Emerald Insight in IJSHE, available at: http://www.emeraldinsight.com/doi/abs/10.1108/IJSHE-12-2013-0166?af=R

energy users ${ }^{8}$. At the extremes, $2 \%$ rated themselves as a very low energy users, and $3 \%$ as a high energy users. However, it is not clear that their understanding of energy consumption was strong enough for respondents to make accurate judgements about their personal use. For example, although 57\% correctly stated that transport and space heating have the potential to produce the greatest savings in domestic energy use, 39\% thought that turning off lights or appliances at the plug had the highest impact on saving energy. Thus, a significant minority of respondents did not have accurate knowledge about how much energy is consumed in different household activities or the most important energy-saving behaviours.

Overall, our findings indicate considerable concern about energy and sustainability, and that many individuals have positive behavioural intentions, but that patchy knowledge about causes and solutions may contribute to ineffective energy-saving behaviours.

\subsection{Sources of information}

In terms of the information sources contributing to their understanding of energy issues, nearly $50 \%$ of student respondents cited formal education (school, college or university) as the main source. However, interesting gender differences emerged, with male students more likely to cite the internet, and females TV or friends and family $(p<0.01)$.

\footnotetext{
${ }^{8}$ It is important to note that these are self-evaluations, so are subject to social desirability bias (a desire in this case to be seen as good 'energy citizens' in a survey on energy literacy) and are not referenced against defined measures of what constitutes low, medium or high energy use.
} 
This is an Accepted Manuscript of an article published by Emerald Insight in IJSHE, available at: http://www.emeraldinsight.com/doi/abs/10.1108/IJSHE-12-2013-0166?af=R

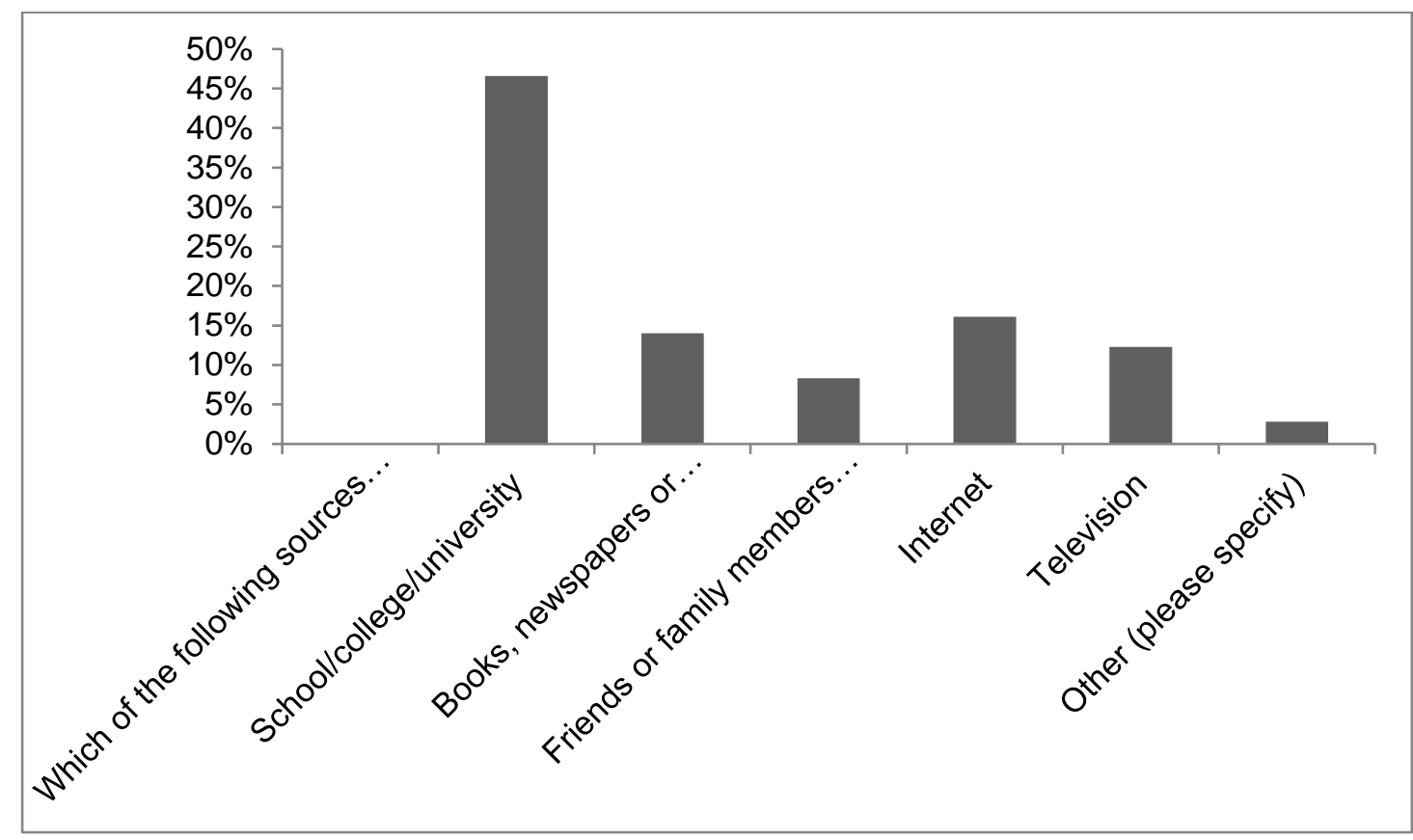

Figure 3: 'Which of the following sources of information has contributed most to your understanding of energy issues? (Please select one answer) $(n=1074)$

Sources of information also differed across disciplines. Geography, Earth \& Environmental Science (GEES) students were significantly more likely than students from other schools $(p<0.01)$ to obtain information about energy from formal education than from other sources. As one said, "I'm an environmental science student, I'm all over this stuff!" (Male) Considerable disciplinary differences in selfreported knowledge also appeared, suggesting that the curriculum content might have an impact on the extent of energy-related knowledge. Over $50 \%$ of respondents from GEES, Marine Science and Engineering, and Architecture stated that they were 'experts' or knew quite a bit about energy (Table 1).

Table 1: Disciplinary differentials on self-assessment of energy knowledge

\begin{tabular}{|l|r|r|r|r|r|}
\hline & $\begin{array}{r}\text { A lot } \\
\text { (expert) }\end{array}$ & $\begin{array}{c}\text { Quite a bit } \\
\text { (informed) }\end{array}$ & $\begin{array}{c}\text { A medium } \\
\text { amount } \\
\text { (somewhat } \\
\text { informed) }\end{array}$ & $\begin{array}{c}\text { Not } \\
\text { much } \\
\text { (novice) }\end{array}$ & Nothing \\
\hline $\begin{array}{l}\text { Architecture, Design and } \\
\text { Environment }\end{array}$ & $17.6 \%$ & $55.9 \%$ & $26.5 \%$ & $0.0 \%$ & $0.0 \%$ \\
\hline Biomedical and Biological Sciences & $4.0 \%$ & $46.7 \%$ & $41.3 \%$ & $8.0 \%$ & $0.0 \%$ \\
\hline Computing and Mathematics & $12.5 \%$ & $42.2 \%$ & $37.5 \%$ & $6.3 \%$ & $1.6 \%$ \\
\hline Education & $0.0 \%$ & $37.9 \%$ & $41.4 \%$ & $17.2 \%$ & $3.4 \%$ \\
\hline
\end{tabular}


This is an Accepted Manuscript of an article published by Emerald Insight in IJSHE, available at: http://www.emeraldinsight.com/doi/abs/10.1108/IJSHE-12-2013-0166?af=R

\begin{tabular}{|l|r|r|r|r|r|}
\hline $\begin{array}{l}\text { Geography, Earth and } \\
\text { Environmental Sciences }\end{array}$ & $7.7 \%$ & $69.2 \%$ & $19.6 \%$ & $2.1 \%$ & $1.4 \%$ \\
\hline Health Professions & $1.8 \%$ & $32.7 \%$ & $47.3 \%$ & $15.5 \%$ & $2.7 \%$ \\
\hline Law & $0.0 \%$ & $23.1 \%$ & $50.0 \%$ & $23.1 \%$ & $3.8 \%$ \\
\hline Management & $1.1 \%$ & $46.8 \%$ & $41.5 \%$ & $10.6 \%$ & $0.0 \%$ \\
\hline Marine Science and Engineering & $9.0 \%$ & $54.9 \%$ & $33.6 \%$ & $2.5 \%$ & $0.0 \%$ \\
\hline Nursing and Midwifery & $0.0 \%$ & $17.6 \%$ & $50.0 \%$ & $32.4 \%$ & $0.0 \%$ \\
\hline $\begin{array}{l}\text { Peninsula School of Medicine and } \\
\text { Dentistry }\end{array}$ & $3.2 \%$ & $30.9 \%$ & $47.9 \%$ & $18.1 \%$ & $0.0 \%$ \\
\hline Psychology & $0.0 \%$ & $17.3 \%$ & $55.6 \%$ & $25.9 \%$ & $1.2 \%$ \\
\hline Social Science and Social Work & $0.0 \%$ & $16.7 \%$ & $54.2 \%$ & $29.2 \%$ & $0.0 \%$ \\
\hline Tourism and Hospitality & $0.0 \%$ & $26.1 \%$ & $52.2 \%$ & $19.6 \%$ & $2.2 \%$ \\
\hline
\end{tabular}

However, the results also indicated a less than clear relationship between subject content and knowledge. This was illustrated by higher than expected self-reported levels of knowledge among Education and Medicine respondents (79\% and $78.8 \%$ respectively informed or somewhat informed, $p<0.01$ ). This perhaps confirms existing research that found levels of sustainability literacy to be influenced by both discipline and the enthusiasm or interest of individual academics (Dawe et al., 2005; Cotton et al., 2009). Interestingly, echoing the findings of the recent NUS surveys (Drayson, Bone and Agombar, 2012), 62\% of respondents either agreed or strongly agreed that energy and environmental education should be a more important aspect of every school and university curriculum.

As might be expected, younger respondents were more likely to state that they had gained the majority of their knowledge from formal learning. The contribution of informal learning was seen among some more mature students, and included both personal and professional influences:

"Married to an environmental lawyer who specialises in energy infrastructure projects!" (Medical student, female)

"Ongoing interest from all sources available (Geography, female) I worked in the industry for 25 years (Marine Science, male)

"Building our own house with energy saving technology" (Occupational therapy, female)

"Environmental science housemate" (History, female)

"Employed by a renewable energy company" (Environmental Science, male) 
This is an Accepted Manuscript of an article published by Emerald Insight in IJSHE, available at: http://www.emeraldinsight.com/doi/abs/10.1108/IJSHE-12-2013-0166?af=R

The role of house-mates was also mentioned as a common influence on energyrelated behaviours, although not always in a positive way:

"I got a recycling bin and put it in our kitchen ... One guy literally refused to recycle, he said I don't have to recycle, I don't want to, it's against my principles."(Architecture, male)

Other respondents specifically mentioned extra-curricular activities, including an optional session on energy during induction week and a leaflet on energy included in welcome packs. However, fewer than half (44.7\%) of respondents belonged to any society at university, and only two belonged to the student Climate Society. Although 13 respondents mentioned the Environmental Society, no forthcoming events could be identified on the Student Union webpage. The low numbers of students who are active in these areas was confirmed by $86 \%$ of respondents, who stated that they never or infrequently 'participate in events run by environmental organizations'.

These findings suggest that there are a number of limitations in both the formal and informal curricula as vehicles for enhancing energy literacy. The nature and influence of the formal curriculum is likely to vary with discipline and the enthusiasm of individual lecturers, while the effects of the informal curriculum are determined somewhat by prior interests (particularly extra-curricular activities) and friendship groups. We therefore now turn to the role of the campus environment as an influence on students' energy literacy.

\subsection{The impact of the campus on energy literacy}

The educational impact of campus energy-saving measures was gauged by asking students about their awareness of university energy-conservation initiatives. Awareness of energy-saving measures was frequently low: $68.5 \%$ felt that not enough information was available on campus energy use, yet $64 \%$ were unaware of the energy certificates displayed in all campus buildings. Respondents were divided on whether the university was doing enough to save energy: $23.3 \%$ of respondents believed there was, but $32.5 \%$ felt there was not, and $44.1 \%$ admitted that they did not know.

$33.3 \%$ of respondents were able to identify at least one energy-saving measure, including: 
- Automatic lighting on motion sensors, and 'turn off lights' notices

- Revolving doors to keep heat in buildings.

- 'Do not waste paper' signs in emails.

- Double-sided printing and fewer handouts

- Automatic sleep functions on computers

- Heat-reflective glass in new marine building

- No parking areas for students to deter driving

- Automatic hand dryers

- Rainwater harvesting

- Solar panels for water heating in Sports Centre

- Halls of residence competition for energy saving run by the student union

Over $10 \%$ of comments mentioned recycling, with some suggesting improvements in this area:

"Plentiful recycling bins (but too little direction of what can be placed into each bin and little coordination of packaging sold on campus and recycling bin availability)." (Medical student, female)

Several respondents also showed detailed knowledge of campus operations, for example, on a recently refurbished building: "it was adapted rather than demolished. The adaptions included solar shading and internal refurbishment which saved huge amounts of waste materials, energy, money and carbon dioxide." (Biomedical Sciences, female) The same student thought the university had "made huge efforts" to make the campus energy efficient but also argued that "there is still room for improvement."

However, the variability in individuals' perceptions was highlighted by the fact that the same areas identified by some respondents as those where the university had taken energy-saving measures were identified by others as areas where energy was being wasted, e.g. lights, computers, heating and automatic doors. Some students also expressed a degree of cynicism about the university's commitment to sustainability, as opposed to saving money, and a minority felt that energy saving was not a priority for students: "I'm paying enough to be at uni; saving energy isn't on my mind." (Anon.) Some disciplinary differences in awareness of initiatives were also apparent (Figure 4). 
This is an Accepted Manuscript of an article published by Emerald Insight in IJSHE, available at: http://www.emeraldinsight.com/doi/abs/10.1108/lJSHE-12-2013-0166?af=R

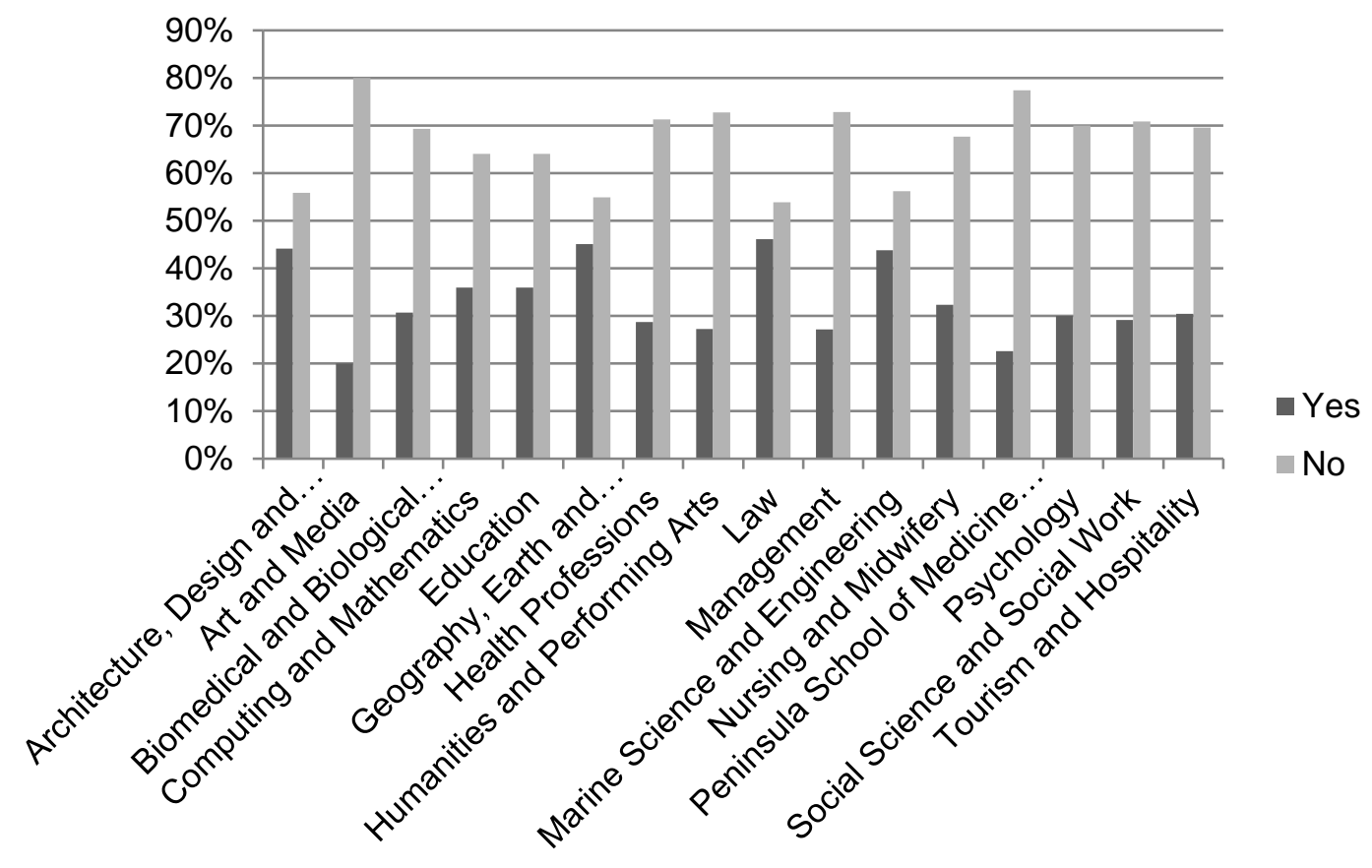

Figure 4. Disciplinary differences in response to the question: Are you aware of any initiatives taken to conserve energy on the Plymouth campus? $(n=1040)$

Again, relatively high proportions of respondents who were aware of initiatives were within Architecture, GEES and Marine Science and Engineering, suggesting that stronger links between curriculum and campus were being made in those areas. However, high levels of awareness were also found in Education and Law, disciplines not always associated with a strong curriculum focus on sustainability. This suggests that influences beyond the formal curriculum may be operating and producing informal learning across the wider student population.

Despite the variations in awareness identified, some respondents indicated support for the university's sustainability initiatives: "I am proud that [the university is] one of the greenest ones." However, when asked about translating this enthusiasm into energy-saving behaviours, $75 \%$ of respondents agreed that stronger visual representations of energy use would make a difference. This issue is currently being pursued at the university, including proposals to visualise the carbon footprint of different campus buildings. 
This is an Accepted Manuscript of an article published by Emerald Insight in IJSHE, available at: http://www.emeraldinsight.com/doi/abs/10.1108/lJSHE-12-2013-0166?af=R

\section{Discussion}

It is clear that multiple factors interact with the formal and informal curricula to influence students' energy literacy. These include:

- Demographic variables (e.g. age, gender)

- Prior experiences (education, work and personal life)

- Discipline of study

- Friendship groups and house-mates

- Extra-curricular activities

- Campus environment

Reinforcing the utility of the concept of energy literacy, this research indicates that knowledge and attitudinal variables are both important contributors to the development of effective energy-saving behaviours. Despite the commonly cited claim that knowledge alone does not engender more sustainable behaviours, it is clearly a contributor to effective behaviour change in this particular context. Anable, Lane and Kelay (2006) identify a set of different types of knowledge they regard as necessary to prompt behavioural modification in relation to climate change. Among the most significant of these is knowledge of: the facts of the issue; the causes and effects of the issue; its urgency and importance; and the contribution of individual behaviour. Based on our research, we would add to this list 'knowledge of the impact of behavioural changes' - since it was clear that students were not well enough informed about basic principles of energy to make rational behavioural choices, even where they possessed knowledge of energy issues at a general level.

However, even knowledgeable students may be reluctant to make significant lifestyle changes in the absence of other motivations. It is here that friendship groups and the wider social environment become crucial. The higher education environment provides a rare opportunity for cognitive, affective and conative aspects of energy literacy to be connected and enhanced. Previous research on the development of commitments to act on sustainability issues, stresses the importance of extracurricular clubs and activities, including volunteering, internships, membership of clubs and societies and attending campus-based sustainability events (Lipscombe, 2008; Hopkinson, Hughes and Layer, 2008). Our research also indicates that informal interactions with friends, house-mates and partners can be important influences on attitudes and behaviours. Equally, the campus environment provides crucial, but often-overlooked, opportunities for sustainability learning that are open to all 
This is an Accepted Manuscript of an article published by Emerald Insight in IJSHE, available at: http://www.emeraldinsight.com/doi/abs/10.1108/IJSHE-12-2013-0166?af=R

students regardless of whatever 'limitations of tunnel vision' (Jucker, 2002 p.13) consciously or unconsciously permeate individual academic disciplines.

The findings illustrate that, even in this leading institution in terms of overall sustainability commitment and performance, there remains scope for further development to catalyse and enhance energy literacy. At an institutional level, the university has strong policies, targets and operational plans to reduce energy use, drawing on available funding streams to achieve savings, and innovative technologies in campus development and improvements. However, exposure to energy issues in the curriculum appears to be patchy, only a minority of students are involved through extra-curricular activities. In addition, energy-saving initiatives on campus are often unseen by students, and there are some indications - as in earlier research - of 'mixed messages' being received which could undermine their efficacy ("Why should I turn off a light when academics fly to the other side of the world for a conference?").

The low awareness of university activities with respect to energy conservation is worrying, as our findings suggest that around half of students acquire their energyrelated knowledge largely through informal learning experiences. Students develop a sense of belonging and identity throughout their time at university which can be transformative in terms of both social and academic development. Yet, with regard to energy literacy, it seems that current achievements are hindered by the lack of effective communication of institutional values, commitment and strategy to students. High visibility and visual interpretations of information about energy use, energy conservation, preferred behaviours as well as the rationale behind these could help to develop the energy literacy of both the institution's staff and that of students.

These findings raise questions about how universities could engage more effectively in developing energy literacy amongst their students. Reconsideration of current practices is needed in order to contribute towards changing students' energy-related attitudes, values and behaviours. One useful way of considering the types of changes that might be required is to revisit the DEFRA 4E model in light of the current findings in order to identify where this university (and most probably other higher education institutions) are performing strongly or less well, and to examine how different components of the $4 \mathrm{E}$ approach might be strengthened. Figure 5 utilises the survey findings to provide a summary of the ways in which universities might contribute more actively towards developing students' energy literacy spanning all aspects of energy literacy, not simply changing behaviours. 
This is an Accepted Manuscript of an article published by Emerald Insight in IJSHE, available at: http://www.emeraldinsight.com/doi/abs/10.1108/IJSHE-12-2013-0166?af=R

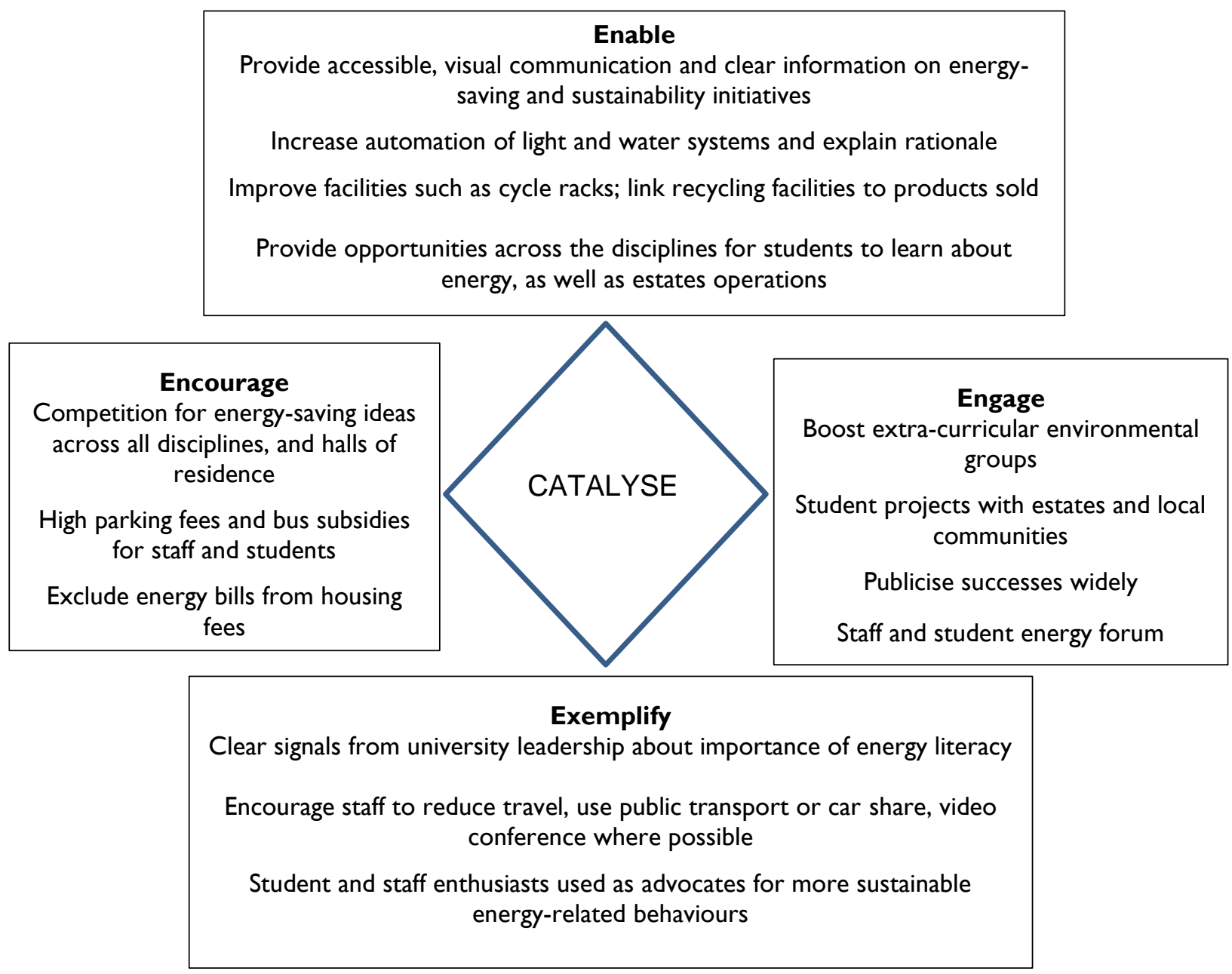

Figure 5. Potential application of the $4 E$ model to energy use within UK universities

Our data illustrate the difficulties in changing behaviour where understanding is only partial (for example, many students prioritise turning off the lights as an energysaving activity despite the relatively trivial energy gains from this action). Enhancing formal and informal learning opportunities is therefore a key element for change. Improving knowledge is far from straightforward, however, not least because energy issues are not integral to all degree programmes therefore strong reliance is placed on the enthusiasm of individual staff members and the uptake of optional induction talks or other extra-curricular opportunities for students throughout their HE experience. Whilst improved signage about energy saving might be helpful, the impact of such informal education techniques relies on students registering and comprehending the messages provided. Figure 5 nonetheless identifies a range of opportunities for increasing students' contact with energy issues that, if utilised energetically and imaginatively, have the potential to contribute towards raising 
This is an Accepted Manuscript of an article published by Emerald Insight in IJSHE, available at: http://www.emeraldinsight.com/doi/abs/10.1108/IJSHE-12-2013-0166?af=R

students' energy awareness and literacy. A large number of these opportunities fall into the enablement category (such as the increase in knowledge and the automation of lighting and water systems which help to routinize energy-efficient behaviours), and the encouragement category (e.g. higher parking fees and public transport subsidies).

However, another crucial element of energy literacy strategies within higher education centres on methods used to engage and encourage students to choose more energy-efficient behaviours. In essence, these rely on universities exemplifying their commitment to energy issues, through the further development of learning opportunities (e.g. competitions and sponsorship of and support for extra-curricular activities) and, crucially, through their own conduct. Clear signals from university leadership provide an important starting point but these need to be supported by consistently applied policies in areas such as travel and buildings policy which send a strong signal that energy (and sustainability more generally) is not being used as a marketing device or is vulnerable to being eroded by other priorities. The important aspect of change in several of these elements is that they include links and synergies with the world outside the campus (community links, travel behaviours etc.). In this way, the enhancement of energy literacy has the potential for wider impact beyond the university community - and is arguably more likely to continue throughout students' future lives.

\section{Study limitations and further research}

Like all research, this study has a number of limitations which should be taken into account when considering the findings. First, it is a single institution case study of a UK university with known leadership credentials in sustainability. Second, the findings are based largely around a survey which achieved a high number of responses but a relatively low overall response rate. These issues are discussed and justified in the methodology section, but they nevertheless place limitations on the generalisability of the findings. Rather than stronger generalisability, therefore, the research offers an indication of the possibilities and problems of promoting energy literacy in the $\mathrm{HE}$ context. The fact that students' energy literacy was somewhat patchy, even within this institution where sustainability is a high priority, adds strength to the argument that much remains to be done to progress this agenda. 
This is an Accepted Manuscript of an article published by Emerald Insight in IJSHE, available at: http://www.emeraldinsight.com/doi/abs/10.1108/IJSHE-12-2013-0166?af=R

The study also offers a potential avenue for future research that focuses more explicitly on institutional and disciplinary differences in energy literacy, and on enhancements to curriculum and campus which might help develop students' energy literacy. Scope also exists for further exploration of the impact of higher education institutions on students' energy literacy and, reciprocally, the impact of students' energy literacy on institutions. In an environment where institutions are attempting to reduce energy use and carbon emissions, enhanced energy literacy could have mutual benefits. However, it is also important to remember that students have limited agency with respect to energy issues during their time at university. Future research might therefore also explore the impact that increasing graduates' energy literacy has on energy-saving behaviours after graduation and in the workplace.

\section{Conclusion and implications}

This research illustrates the importance of both formal and informal curricula in the development of students' cognitive, affective and conative energy literacy. Although differences in energy literacy between disciplines were identified, knowledge about energy was certainly not limited to specific subjects, suggesting that scope exists for

the further development of energy literacy within aspects of the formal curriculum. In addition, the informal and campus curriculum (including extra-curricular activities and social learning) emerged as important influences on students' attitudes and behaviours. Taken together, these findings offer indicators for how higher education institutions might enhance the energy literacy of their students, while the 4E model provides a useful framework for identifying and structuring future developments. Also important in this context are the potential lessons to be gained from studying an institution which has gone some way towards embedding sustainability across its curriculum and campus activities. Although the evidence from the study suggests that the value of the case study lies equally in understanding failures and successes, the sharing of experiences in this way may provide lessons for universities at different stages in the broader effort to integrate sustainability concerns into higher education. 
This is an Accepted Manuscript of an article published by Emerald Insight in IJSHE, available at: http://www.emeraldinsight.com/doi/abs/10.1108/IJSHE-12-2013-0166?af=R

\section{References}

Anable, J., Lane, B., and Kelay, T. (2006) An evidence base review of public attitudes to climate change and transport behaviour. Final report. London: Department for Transport.

Attari, S. Z., DeKay, M.L., Davidson, C.I. and Bruine de Bruin, W. (2010), "Public perceptions of energy consumption and savings", PNAS, Vol. 107 No.37, pp. 6.

Barrow, L. and Morrissey, J.T. (1989), "Energy Literacy of Ninth-Grade Students: A Comparison between Maine and New Brunswick", The Journal of Environmental Education, Vol. 20 No. 2, pp. 4.

Barth, M. (2013), "Many roads lead to sustainability: a process-oriented analysis of change in higher education", International Journal of Sustainability in Higher Education, Vol. 14 No. 2, pp. 160-175.

Bodzin, A. 2012. Investigating urban eighth-grade students' knowledge of energy resources. International Journal of Science Education 34, no. 8: 21.

Brewer, R.S., G.E. Lee, and P.M. Johnson. 2011. The Kukui Cup: a Dorm Energy Competition Focused on Sustainable Behavior Change and Energy Literacy. Paper to 44th Hawaii International Conference on System Sciences (HICSS).

Cotton, D., Bailey, I., Warren, M. \& Bissell, S. (2009), "Revolutions and second-best solutions: Education for Sustainable Development in Higher Education", Studies in Higher Education, Vol. 34 No. 7, pp. 719-733.

Cotton, D. R. E. and Alcock, I. (2012), "Commitment to environmental sustainability in the UK student population", Studies in Higher Education, Vol. 38 No. 10.

Curry, T.E., D.M. Reiner, M.A. de Figueiredo, and H.J. Herzog. 2005. A survey of public attitudes towards energy \& environment in Great Britain. MIT Laboratory for Energy and the Environment, MIT Working Paper LFEE 2005-001.

Dahle M, and Neumayer E. (2001), "Overcoming barriers to campus greening: A survey among higher educational institutions in London, UK", International Journal of Sustainability in Higher Education, Vol. 2 No. 2, pp. 139 - 160.

Dawe, G., Jucker, R., and Martin, S. (2005), Sustainable development in higher education: Current practice and future developments. A report for the Higher Education Academy, York, UK.

DeWaters, J. 2009. Work in Progress - Energy Education and Energy Literacy: Benefits of Rigor and Relevance. Paper to IEEE Frontiers in Education Conference, 2009. 18-21 October, San Antonio Texas.

DeWaters, J.E. \& Powers, S.E. (2011), "Energy literacy of secondary students in New York State: A measure of knowledge, affect and behaviour", Energy Policy, Vol. 39 No. 3, pp. 1699-1710. 
This is an Accepted Manuscript of an article published by Emerald Insight in IJSHE, available at: http://www.emeraldinsight.com/doi/abs/10.1108/IJSHE-12-2013-0166?af=R

DEFRA (2005), Changing behaviour through policy making, Department for Environment, Food and Rural Affairs, London available at: http://archive.defra.gov.uk/sustainable/government/documents/change-behaviourmodel.pdf (accessed 20th December 2013)

DEFRA (2008), A framework for pro-environmental behaviours, Department for Environment, Food and Rural Affairs, London.

Djordjevic, A. and Cotton, D.R.E. (2011), "Communicating the Sustainability Message in Higher Education Institutions", International Journal of Sustainability in Higher Education, Vol. 12 No. 4, pp. 381-394.

Du Plessis, A. J., P.S. Nel, and S. Al-Shamaa. 2012. The Perceptions of Tertiary Students towards Environmental Sustainability: Some Empirical Evidence from A Longitudinal Study. World Review of Business Research 2, no. 3: 43-62.

Drayson, R., Bone, E. and Agombar, J. (2012), Student attitudes towards and skills for sustainable development, NUS/HEA, York, available at:

http://www.heacademy.ac.uk/assets/documents/esd/Student attitudes towards and skills for sustainable development.pdf (accessed 20th December 2013)

Dunlap, R.E. K.D. Van Liere, A.G. Mertig, and R.E. Jones. 2000. New trends in measuring environmental attitudes: measuring endorsement of the new ecological paradigm: a revised NEP scale. Journal of Social Issues 56, no. 3: 425-442

Dunlap, R. E. (2008), "The new environmental paradigm scale: From marginality to worldwide use." The Journal of Environmental Education Vol. 40 No. 1, pp. 3-18.

Dwyer, C. 2011. Developing an Energy Literacy Curriculum in Support of Sustainability. [Available at SSRN: http://ssrn.com/abstract=1801463]

Emanuel, R. and Adams J.N. (2011), "College students' perceptions of campus sustainability", International Journal of Sustainability in Higher Education, Vol. 12 No. 1, pp.79- 92.

Giddens, A. (1991), Modernity and Self Identity. Self and Society in the Late Modern Age. Cambridge, Polity.

Hammersley, M. (1998) Reading Ethnographic Research: A Critical Guide, 2nd edn (London: Longman).

Hawcroft, L. J. and T. L. Milfont (2010), "The use (and abuse) of the new environmental paradigm scale over the last 30 years: A meta-analysis", Journal of Environmental Psychology, Vol. 30 No. 2, pp. 143-158.

HEFCE (2008), Strategic review of sustainable development in higher education in England

HEFCE (2013), Sustainable development in higher education: Consultation on a framework for HEFCE, available at: http://www.hefce.ac.uk/media/hefce/content/pubs/2013/201331/2013 31.pdf (accessed 20th December 2013). 
This is an Accepted Manuscript of an article published by Emerald Insight in IJSHE, available at: http://www.emeraldinsight.com/doi/abs/10.1108/IJSHE-12-2013-0166?af=R

Holden, C. and Barrow, L.H. 1984. Validation of the test of energy concepts and values for high school. Journal of Research in Science Teaching 21, no. 2: 187-196.

Holmes, B. 1987. Energy: Knowledge and Attitudes, A National Assessment of Energy Awareness among Young Adults. Department of Education, Commission of the States, Colorado National Assessment of Educational Progress.

Hopkinson, P., Hughes, P. and Layer, G. (2008), "Sustainable graduates: Linking formal, informal and campus curricula to embed education for sustainable development in the student learning experience", Environmental Education Research, Vol. 14 No. 4, pp. 435-454.

Jucker, R. (2002), Our common illiteracy: Education as if earth and people mattered, Peter Lang, Frankfurt.

Kagawa, F. (2007), "Dissonance in students' perceptions of sustainable development and sustainability: implications for curriculum change", International Journal of Sustainability in Higher Education, Vol. 8 No. 3, pp. 317-338.

Kurland, N. B. (2011), "Evolution of a campus sustainability network: a case study in organizational change", International Journal of Sustainability in Higher Education, Vol. 12 No. 4, pp. 395-429.

Lipscombe, B. P. (2008) Exploring the role of the extra-curricular sphere in higher education for sustainable development in the United Kingdom. Environmental Education Research 14 (4): 455-468.

Lundmark, C. 2007. "The new ecological paradigm revisited: Anchoring the NEP scale in environmental ethics." Environmental Education Research 13(3): 329-347.

Martin, S. and R. Jucker (2005), "Educating earth-literate leaders", Journal of Geography in Higher Education, Vol. 29 No. 1, pp. 19-29.

O'Riordan, T. 1981. Environmentalism. Pion Books, London.

Orr, D.W. (1994), Earth in mind: On education, environment, and the human prospect, Island Press, Washington:

Poortinga, W., N. Pidgeon, and I. Lorenzoni. 2006. Public Perceptions of Nuclear Power, Climate Change and Energy Options in Britain. Summary findings of a survey conducted during October and November 2005. Understanding Risk Working Paper 06-02. Norwich: Centre for Environmental Risk, University of East Anglia.

Shephard, K., Mann, S., Smith, M., \& Deaker, L. (2009), "Benchmarking the environmental values and attitudes of students in New Zealand's post-compulsory education", Environmental Education Research, Vol. 15 No. 5, pp. 571-587.

Silverman, D. (2005), Doing qualitative research ( $2^{\text {nd }}$ edition), Sage Publications, London.

Stake, R.E. (1995), The Art of Case Study Research, Sage Publications, London.

Sterling, S. Maxey, L and Luna, H. (Eds) (2013), The sustainable university: Progress and prospects, Routledge, Abingdon. 
This is an Accepted Manuscript of an article published by Emerald Insight in IJSHE, available at: http://www.emeraldinsight.com/doi/abs/10.1108/IJSHE-12-2013-0166?af=R

Stewart, M. (2010), "Transforming higher education: a practical plan for integrating sustainability education into the student experience", Journal of Sustainability Education, Vol. 1, pp. 195-203.

Stibbe, A. (2009), The handbook of sustainability literacy: skills for a changing world. Green Books, Totnes.

Tilbury D. (2011), "Higher education for sustainability: A global overview of commitment and progress." In GUNI (Ed.), Higher education's commitment to sustainability: From understanding to action (pp. 18-28), GUNI Higher Education in the World 4, Barcelona.

Van Treuren, K.W. and Gravagne, I.A. (2008), "Raising community energy awareness: building an energy display at the Mayborn Museum." Proceedings of the 2008 ASEE Gulf-Southwest Annual Conference, The University of New Mexico - Albuquerque (pp. 1-11).

Wiek, A., Withycombe, L. and Redman, C.L. (2011), "Key competencies in sustainability: a reference framework for academic program development", Sustainability Science, Vol. 6, pp. 203-218.

Winter, J. and Cotton, D.R.E. (2012), "Making the Hidden Curriculum Visible: Sustainability Literacy in Higher Education", Environmental Education Research, Vol. 18 No. 6, pp. 783-796. 
This is an Accepted Manuscript of an article published by Emerald Insight in IJSHE, available at: http://www.emeraldinsight.com/doi/abs/10.1108/IJSHE-12-2013-0166?af=R

\section{Biographical details:}

\section{Professor Debby Cotton}

Debby Cotton is Professor of Higher Education Pedagogy and Head of Educational Development in the Pedagogic Research Institute and Observatory (PedRIO), Plymouth University, UK. She has a doctorate in Education from Oxford University, and has published widely on a range of higher education topics, specialising in sustainability in higher education. For full list of research interests and publications, see http://www.plymouth.ac.uk/staff/dcotton

\section{Dr Wendy Miller}

Wendy Miller is a Research Assistant in the Pedagogic Research Institute and Observatory (PedRIO) at Plymouth University and an Associate lecturer in Educational Development. She has a PhD in human geography from Plymouth University.

\section{Dr Jennie Winter}

Jennie Winter is an Educational Developer in the Pedagogic Research Institute and Observatory (PedRIO) at Plymouth University. Her interests include Education for Sustainability, Research-Informed Teaching and Arts Pedagogy. For more information please visit http://www.plymouth.ac.uk/staff/j1winter

\section{Dr Ian Bailey}

Ian Bailey is an Associate Professor in Human Geography at Plymouth University. He is a member of the Centre for Research in Environment and Society and specialises in environmental politics and social attitudes to sustainability issues. Further details of his interests can be found at: http://www.plymouth.ac.uk/staff/ibailey

\section{Professor Stephen Sterling}

Stephen Sterling is Professor of Sustainability Education at Plymouth University and head of the Centre for Sustainable Futures. A former Senior Advisor to the UK Higher Education Academy on Education for Sustainable Development (ESD), he has worked as a consultant in environmental and sustainability education in the academic and NGO fields nationally and internationally for around three decades. Books include Sustainability Education: Perspectives and Practice Across Higher Education (coedited with David Selby and Paula Jones) Earthscan 2010; and The Sustainable University - progress and prospects (co-edited with Larch Maxey and Heather Luna) Earthscan/Routledge 2013 